\title{
Political Marketing: An Effective Strategy for Quality Leadership and Sustainable Democracy in Nigeria
}

\author{
Olafemi Ayopo Olotu ${ }^{1} \&$ Victor Olukayode Ogunro ${ }^{2}$ \\ ${ }^{1}$ Department of Business Administration, College of Management Sciences, Federal University of Agriculture, \\ Makurdi, Benue State, Nigeria \\ ${ }^{2}$ Department of Marketing, Rufus Giwa Polytechnic, Owo, Ondo State, Nigeria \\ Correspondence: Olafemi Ayopo Olotu, Department of Business Administration, College of Management \\ Sciences, Federal University of Agriculture, PMB 2373, Makurdi, Benue State, Nigeria. E-mail: \\ femolotung@yahoo.com
}

Received: September 16, 2012 Accepted: November 17, 2012 Online Published: January 17, 2013

doi:10.5539/ijms.v5n1p128 URL: http://dx.doi.org/10.5539/ijms.v5n1p128

\begin{abstract}
Democracy stands for the rule of law, mutual consultation in matters of governance and the safeguarding of human rights brought about through quality leadership. This philosophical view forms the political hallmark of any nation including Nigeria. Unfortunately, democratization in Nigeria has remained nascent and quality leadership a mirage. This was largely due to the mis-conception given to the exchange theory concept in the Politician-Electorate relationships. The study identified Apolitical Marketing as the bane of sustainable democracy in Nigeria, thus the non-application of the concept of "customer first" (Electorate) is responsible for poor leadership. The author revealed that Political Marketing Research, Internal Democracy, Relational Politics and Green Politics are holistic in the drive toward good leadership and democratic sustainability. It was thus, recommended that Nigeria political class, umpires and leaders should invest very high proportion of their resources on research and intelligence gathering on the voters and embraces the holistic marketing concept geared toward a lasting, enduring and beneficial democracy.
\end{abstract}

Keywords: political marketing, democracy, leadership, internal marketing, relational marketing, green marketing, marketing research

\section{Introduction}

The creation of Nigeria by the British imperial power gave birth to the plethora of constitutions before and after independence. This trial by error ways of governance was meant to lead the country toward sustainable democracy, unfortunately, this has not been the case since 1960 when Nigeria got her independence and subsequently, adopted the federal system of government. Ekuwueme (2005) posits that, the constitution is a necessary, if not sufficient element for sustainable democracy in any election, including Nigeria. This is because; the tenets of democracy of a nation, the democratic principles, limitations, privileges, definitions and procedures are captured in the constitution.

The military intervention, though a diversion, created decrees that guides our co-existence. This militarocracy has been an impediment toward democratic governance that requires time to form, grow, mature and sustaining. It was Mahmud Tukur in, Shekarau (2005) who posits that "the country is still searching for a system which will enable it to develop effective and efficient institutions and a style of government which will facilitate the creation of a civil polity and the tackling of social-political and economic problems in a manner harmonious with the worldview, way of life and temperament of the population". This search has culminated in series of political and constitutional conferences geared toward sustaining democracy in Nigeria.

Democracy is the government of the people by the people and for the people. Ogunleye (2005) argued that democracy is people initiated, people promoted, sustained by the people for the benefit of the people. The people only cannot democratize without these anchoring factors such as the constitution, respect for rule of law, strong institutions, independent electoral system, education, security end a buoyant economy.

In Nigeria, democracy has been a familiar word that all and sundry projected would salvage the country from the doldrums of abject poverty and economic destruction. Odunze (2010) argued that the most fundamental precept 
of democracy is the freedom of citizens to elect their leaders. Good leadership is one of the measures of sustainable democracy and electing good leaders requires interaction between political players and the electorate.

The dividend of democracy and its sustainability can only be attain and enjoy when there is a synergy between party operators and voters in generating acceptable platform through which quality leaders are elected, monitored, evaluated and re-elected. This process is similar to the concept of marketing where there is a mutual relationship between the customer and the producer that leads to satisfactory exchange.

In order for the marketing organization to remain in business with an increased market share and profit, there must be an enhanced value creation that would serve the needs of the customer satisfactorily. In return, the customers would not only stick to the brand but also advocate for the firm.

In the leadership selection processes of any nation including Nigeria, political aspirants seek for the votes of the people and in return, the government offer good governance. Scammel (1995) posits that the application of marketing concepts in politics may results in politics becoming more democratic. This was further emphasized by Nazar et al., (2010) that political marketing is very useful to the political parties and the democratic governments for establishing long-term relationships with the electoral publics, especially in developing and underdeveloped countries. If marketing is used to sustain customer/producer relationships then political marketing is a veritable tool for sustaining democracy. This research work is therefore directed toward the application of Political Marketing Orientation (PMO) in a political system and its impact toward ensuring quality leadership and sustaining democracy in Nigeria.

\section{Democratization in Nigeria}

Federalism is a system of governance where constitutional powers are the hallmark of government at all levels. This form of government allows democracy to thrive through constitution, power of the people and rule of law application. Nigeria as a Nation was amalgamated in 1914 by Lord Luggard and became a federation in 1954 through the Lyttleton constitution. A federal system of government is a system whereby the powers of government are divided between the national or central government and government of the component states or regions, with legal autonomy (Ozoigbo,2006). These divided responsibilities as contained in the Nigeria constitution has elicited marginality among the component regions. No wonder Ekwueme (2005) observed that, the structure of the Nigerian federation at independence was a recipe for instability and failure of sustainable democracy.

The agitation of the minority for recognition led to the creation of the mid-western region in 1963 and from then till 1996, Nigeria was divided into 36 states in six geo-political zones.

In the first republic, Nigeria has a strong federating units and a weak centre. Then the region was more attractive than the centre and the leaders were more responsive with purposeful leadership. The intervention of the military government truncated a growing democracy and these intermittent interferences for a cumulative period of over 35 years of Nigeria 50 years independence, has shoved Nigeria aside in democratic pursuit. Ozoigbo (2006) concluded that democracy can never blossom in a military government. In 1979, an attempt to democratize the federating unit of Nigeria was once again truncated in 1983, when the politicians were divided in the line of ethnicity, winner takes all and political gangsterism. In 1993, a free and fair election was botched by the military and power players in the country, thereby denying Nigerians a process of democracy and the need to elect their choice in anticipation of good leadership. This "political abortion" has indeed created health challenge in the Nigeria political system and ultimately death of sustainable democracy. 1999 brought another opportunity for Nigeria to commence a democratization process that saw a multi-party system that brought an appointed General Olusegun Obasanjo into power. Though, we may have had twelve (12) years of democratic rule, but how democratic are the processes. The elections were fraught with violence, imposition, killing, intimidations, monetary inducement and worse still bad leadership, with dividend of democracy only found in the corridors of very few in power.

The agitation for resources control, marginalization, people oriented constitution, self determination, tenure elongation, Regional dichotomy, and good governance was due to the absence of effective Political Marketing in the Nigeria democratization process.

Politics is highly competitive, as such the participants (politicians), whose aim is to be in office of leadership and control power, must apply the principles of marketing to be accepted by the electorate, remains in the heart of the people and possibly enjoy a second tenure. 


\subsection{Political Marketing Orientation (PMO) and the Nigeria Electoral System}

Political marketing is relatively a new concept in the Nigeria political landscape. Market Orientation was first mentioned in the political contest in the early 1990s (Newman 1994). While, 0'cass (2001) and Ormrod (2005) wrote articles on Marketing Orientation of political parties, where they viewed Political Marketing Orientation as the analysis, planning, implementation and control of political and electoral campaigns. Though, this gave the understanding of political marketing management. In the same light, Niffenger (1989) posits that PMO is a marketing designed to influence target audience to vote for a particular person, party or proposition. Political Marketing is intrinsically linked with political campaigns, winning elections and maintaining leadership positions, using certain techniques (Butler and Collins, 1994; Newman, 1994; Henneberg, 2003).

Political marketing include communication and public relations, and this position was supported by kavanagh (1996) and Scammell (1995) when they argued that, PM is electioneering that include a set of strategies and tools to trace and study public opinion before and during an election campaigns, to develop campaign communications and to assess their impact. There is the need to keep constant interaction with voters, as well as, effective internal marketing. Lock and Harris (1996) pointed out that, political marketing is concerned with communicating with party members, media and prospective sources of funding, as well as, the electorates.

Political Marketing Orientation takes into cognizance the marketing-mix concept, this involves the (1) products-candidate, policy ideology and good governance (LeBaron, 2008 and Nazar, et al., 2010); (2) Distribution, Henneberg (2003) concluded that distribution in PMO refers to the way and manner the products are made available to the target market (voter) and these are campaign delivery and offering delivery; (3) Price (cost)-In political marketing, costs deals with the management of attitudes and behaviours of all the political players, internally and externally. Niffenger (1989) recognizes psychological costs, opportunity cost in decision making and voting influence costs. It is imperative, that these costs must be minimized, most especially, on the part of the voters; (4) Communication - this essentially deals with information dissemination. This is very important among key officers (internal) and other stakeholders (external). O'cass (2001) posits that communication in PMO, deals with designing contents of political campaigns and future programmes.

In line with the above concept of marketing mix in politics, one may conclude that political activities are based on the exchange theory. Gbadeyan (2011) argued that, political parties seek voters support in exchange for good governance. Good governance is a measure of sustainable democracy, it therefore implies that with the effective application of political marketing, system of governance may improve.

\subsection{Sustainable Democracy through Political Marketing Orientation}

The failure of political parties in Nigeria to appreciate, acknowledge and accept voters as having the ultimate powers as kept politicians in the doldrums of mass marketing characterized by crisis and conflicts. This is the era where the concept of marketing was the production of any product for the consumers without their inputs (Anyhow, they will buy).

Marketing according to Kotler (2001) involved not only goods and services, but also entities like experiences, events, persons, places, properties, organizations, information and ideas. This implied that for a customer to be satisfied and possibly be identifying with a particular brand of a product, the value chain must go beyond the product. It is therefore pertinent that in political marketing, these understand must be well enshrined and accepted. In order to create and establish cordiality in the Nigerian political arena that would engender democratic sustainability, these holistic marketing orientation must come to play.

\subsubsection{Marketing Research}

Zikmund (1997) viewed marketing research as the systematic and objective process of generating information to aid marketing decisions. Ekerete (2003) argued that research is fundamental to everything we do so much so, that we hardly make any significant decision without the benefit of some kind of marketing research. In our context, it is good to note that prime leadership value of marketing research comes from reduced uncertainty through information that facilitates decision making about political strategies and tactics to achieve democratic strategic goals. The application of marketing research in the political processes otherwise refers to as Political marketing Research;

- Enables electoral umpires develop strategies that would ensure free, fair and all inclusive elections that would be generally accepted and reduce litigations.

- Would help Political parties to analyze and select target voters. Newman (1999) recalled in 1960 when Kennedy aides organized piles of three-by-five index cards, each representing a targeted voter to mobilize in the 
crucial West, virginal and Wisconsin primaries. In essence, it would aid candidates in identifying segments that would be receptive to their manifestoes and candidates

- Allows Political parties to have access to information that would be beneficial to both the party and the electorates. LeBaron (2008) observed the employment of Richard Wirthlin by Ronald Reagan in 1980 to conduct polls and generate market intelligence. A database was generated called "Political Information System" (PINS) to predict who would vote and how they would vote.

- Makes Political leaders elected into any of the offices have first-hand information on the needs of the electorates, how and when these needs are met in order of priorities to the satisfaction of all parties.

- Would encourage Political players - parties, electoral officers, political workers etc have "voter's first" approach. The whole players geared their efforts toward satisfying voters' wants and needs- right candidate, free and fair election, good governance and secured environment. Scammel (1995) observed that the old-model of "educating voters about a candidate" has given way for "educating politicians about the voters". This was observed in the 2011 elections, especially the Presidential election where PDP directed all her efforts toward the voters, got their attention, confidence and votes.

\subsubsection{Internal Marketing}

Kotler (2005:697) observed that everyone in the organization buy into the concepts and goals of marketing and engage in choosing, providing and communicating customer value. Marketing activities within the organization is as important as, external marketing.

Internal marketing according to Kotler takes place at two levels i.e. the various marketing functions which must work together and that marketing must be embraced by all the departments. This implies that, internal democracy and sense of belonging must be enshrined in party's internal administrations, political ideology, culture and political products must be well communicated and accepted by all the party hierarchies before selling it to the electorates. Everyone in the party must think electorate all the time, and given equal opportunity to elect and be elected. This is internal Democracy applying the principles of internal marketing. O' Shaughnessy et al. (2012) argued that control of symbolism and personality is outside the control of the party due to the dynamism of the environment, as such, a well coordinated and united party can positively influence the political environment to their advantages.

\subsubsection{Relational Marketing (RM)}

In recent time, relational marketing has replaced transactional marketing in the exchange processes between the marketer and the customer. Morgan and Hunt (1994) viewed relationship marketing as a marketing activity directed toward establishing, developing and maintaining successful relational exchange. No wonder Holstius and Kaynak (1995) concluded that the benefit of RM is Mutual.

In our context, this could be seen as Relational Politics, which has the aim of building mutually satisfying long-term relationships with key players in the political arena. These include electorates, political umpires, security operatives, media, members, oppositions, sponsors and the general public. In a relational situation, all registered members of the party will be united and have sense of responsibility toward the party. Olotu (2010) and Sin et al (2002) discovered seven dimensions of relationship marketing; (i) Trust; (ii) Bonding; (iii) Communication; (iv) Empathy; (v) Reciprocity; (vi) Shared value and (vii) Sociality. The effective integration of the underpinnings of Relationship Marketing in the Relational Politics approach would engender economic, technical and social ties between parties and electorates.

\subsubsection{Green Marketing}

It is just not enough to market product or service to the consumers, but the welfare of the consumers must also be a priority to the marketer. The best long-run interest of the consumer and the society at large must take the front burner in the face of profit maximization.

Kotler (2005) and Ekerete (2002) posit that, the societal marketing concept calls upon organization to build social and ethical considerations into their marketing practices. In essence, political gladiators must be "green" or "socially responsible" in their political exchange processes. The game of politics must be played on the field of ethical, environmental, legal and social context. The constitution has created institutions, laws and ethics of the game and this must be strictly adhere to in order to have violence free democratic process. Green Politics would thus, reduce political violence, winner-takes-all, disrespect for rule of law, corruption, do or die, hooliganism, ethnicity and political fraud in the Nigeria political landscape. 


\section{Conclusion}

It is no gain saying that politics in Nigeria is a charade. This shenanigan has created worse leaders in our fifty-one years of independence. Nigeria has never no piece as we moved from one despotic military rule to another and the jingle bell of civilian rule (elections) bring forth blood birth, deceit, looting and hatred that eventually took us one more step backward democratically. Democracy in Nigeria is yet to find its root due to the non introduction and practice of holistic marketing principles in the political processes. This has largely contributed to its expensiveness, corruption, cumbersomeness, winner takes all and lack of democratic dividends for the populace. A faulty foundation leads to total collapse, thus the political concept must be centered on the electorate, if democracy must thrive in Nigeria. The leadership we desire for good governance and sustainable democracy must be a leader that is transparently selected and elected through a free and fair election; participated, monitored and accepted by the electorate. This can only be achieved through the application of Holistic marketing concept in the Nigerian political practices, i.e. "everything matters" with marketing. It is therefore expedient that Political Marketing Research, Internal Democracy (Marketing), Relational Politics (Marketing) and Green Politics (Marketing) be made basic fundamental ingredients of political participation in Nigeria, in order to engender quality leadership, sustainable democracy and peace.

\section{Recommendations}

In view of the discoveries in this paper, it is recommended that:

1) Nigeria politicians should as a matter of ideology embrace the principle of marketing by seeing the electorate as the king and not the product.

2) Quite a large percentage of the finances of the party must be spent on research and intelligence gathering on issues associated with the needs and wants of the electorate.

3) Internal democracy should be highly encouraged, monitored and ensure adherence within the political parties

4) Green politics should form the fulcrum of the political parties and the umpires' activities. Laws must be obeyed, ethics must be followed and the electorates must not suffer in any way, as a result of the political players activities.

5) Political relationships must be seen to be genuine and built on the highlighted dimensions of Relationship Marketing.

6) Political marketing should be introduced as a discipline in the educational institutions of the country, most especially, the Independent National Electoral Commission Training Institute.

\section{References}

Butler, P., \& Collins, N. (1994). Political Marketing Structure and Process. European Journal of Marketing, 28(1), 19-34. http://dx.doi.org/10.1108/03090569410049154

Ekwueme, A. (2005). The Constitution and Sustainable Democracy in Nigeria: Challeges and Prospects. A paper delivered at the international conference by foundation for good governance \& development in Nigeria, London, Sat, June.

Gbadeyan, R. A. (2011). Political Marketing Strategies and Democracy in Nigeria. Asian Journal of Business Management, 3(1), 8-17.

Henneberg, S. C. (2003). Generic Functions of Political Marketing Management, University of Bath, School of Management. Working Series: 19.

Holstius, K., \& Kaynak, E. (1995). Retail Banking in Nordic Countries: the case of Finland. International Journal of Bank marketing, 13(8), 10-20. http://dx.doi.org/10.1108/02652329510098873

Kavanagh, O. (1996). New Campaign Communication Consequences for Political Parties. Harvard int'l Journal, $1(3), 60-76$.

Kotler, P. (2001). Marketing Management: The Millennium Edition, prentice Hall. New Delhi, private Ltd: 1-32.

Kotler, P., \& Keller, K. L. (2005). Marketing Management (12th ed.). New Delhi, prentice Hall; 18-20.

LeBaron, D. (2008). Essays in Political Marketing. Doctoral Thesis/Dissertation, (PhD). The Pennsylvania State University, USA.

Lock, A., \& Harris, P. (1996). Political Marketing Vive la difference. European Journal of marketing, 30(10/11), 21. http://dx.doi.org/10.1108/03090569610149764 
Morgan, R. M., \& Hunt, S. D. (1994). The commitment-Trust theory of Relationship Marketing. Journal of Marketing, 58(1), 20-38. http://dx.doi.org/10.2307/1252308

Nazaar, M. S., Latif, A., \& Yaqub, M. C. (2010). Scope and Dynamics of Political Marketing in Pakistan's Business Administration. International Bulletin of Business Administration, 7, 15-21.

Newman, B. I. (1994). The Marketing of the President; Political Marketing as Campaign Strategy. Thousand Oaks, sage, C.A.

Newman, B. I. (1999a). Handbook of Political Marketing. Thousand Oaks, sage, CA.

Niffeneager, P. B. (1989). Strategies from the Success of Political Marketing. Journal of Consumer Marketing, 6(1), 45-61. http://dx.doi.org/10.1108/EUM0000000002539

O' Cass, A. (2001). Political Marketing. European Journal of Marketing, 35(9/10), 1047-1057. http://dx.doi.org/10.1108/03090560110401956

O’ Shaughnessy, N. J., O'cass, A., Baines, P., \& Ormrod, R. P. (2012). Political Marketing Orientation: Confusions, Complications and Criticisms. Journal of Political Marketing, 11.

Odunaze, H. (2010). There is more to Democracy than Voting.

Ogunleye, O. (2005). Pillars of a Sustainable Democracy. Retrieved from http//www.nigeriavillagesquare.com.

Opara, B. C., Olotu, O. A., \& Maclayton, D. W. (2010). Analysis of impact of Technology on Relationship Marketing Orientation and Bank Performance. European Journal of Scientific research, 45(2), Sept. 2010.

Ormrod, R. P. (2005). A Conceptual Model of Political Market Orientation. Journal of Non- profit and Public sector marketing, 14, 47-64. http://dx.doi.org/10.1300/J054v14n01_04

Scamell, M. (1995). Designer Politics. Bassingstock macinillan, Basingstoke.

Shekaran, M. I. (2005). Leadership as a Trust: Role in Sustaining a Viable Democratic Culture in Nigeria. A paper delivered at the international conference by foundation for good governance \& development in Nigeria, London, Sat, June.

Sin, L. Y. M., Tse, A. C. B., \& Yau, O. H. M. (2002). The Effect of Relationship Marketing Orientation on Business Performance in a service-oriented economy. Journal of Services marketing, 16(7), 656-676. http://dx.doi.org/10.1108/08876040210447360 